\title{
Minimally Invasive Techniques to Accelerate the Orthodontic Tooth Movement: A Systematic Review of Animal Studies
}

\author{
Irfan Qamruddin, ${ }^{1}$ Mohammad Khursheed Alam, ${ }^{2}$ \\ Mohd Fadhli Khamis, ${ }^{3}$ and Adam Husein ${ }^{4}$ \\ ${ }^{1}$ Orthodontic Department, Baqai Medical University, P.O. Box 2407, Karachi, Pakistan \\ ${ }^{2}$ Orthodontic Unit, School of Dental Sciences, Universiti Sains Malaysia, Health Campus, Kota Bharu, Kelantan, Malaysia \\ ${ }^{3}$ Forensic Dentistry Unit, School of Dental Science, Universiti Sains Malaysia, Health Campus, Kota Bharu, Kelantan, Malaysia \\ ${ }^{4}$ Prosthodontic Unit, School of Dental Sciences, Universiti Sains Malaysia, Health Campus, Kota Bharu, Kelantan, Malaysia
}

Correspondence should be addressed to Mohammad Khursheed Alam; dralam@gmail.com

Received 29 September 2015; Accepted 6 December 2015

Academic Editor: Andrea Scribante

\begin{abstract}
Copyright (C) 2015 Irfan Qamruddin et al. This is an open access article distributed under the Creative Commons Attribution License, which permits unrestricted use, distribution, and reproduction in any medium, provided the original work is properly cited.

Objective. To evaluate various noninvasive and minimally invasive procedures for the enhancement of orthodontic tooth movement in animals. Materials and Methods. Literature was searched using NCBI (PubMed, PubMed Central, and PubMed Health), MedPilot (Medline, Catalogue ZB MED, Catalogue Medicine Health, and Excerpta Medica Database (EMBASE)), and Google Scholar from January 2009 till 31 December 2014. We included original articles related to noninvasive and minimally invasive procedures to enhance orthodontic tooth movement in animals. Extraction of data and quality assessments were carried out by two observers independently. Results. The total number of hits was 9195 out of which just 11 fulfilled the inclusion criteria. Nine articles were good and 5 articles were moderate in quality. Low level laser therapy (LLLT) was among the most common noninvasive techniques whereas flapless corticision using various instruments was among the commonest minimally invasive procedures to enhance velocity of tooth movement. Conclusions. LLLT, low intensity pulsed ultrasound (LIPUS), mechanical vibration, and flapless corticision are emerging noninvasive and minimally invasive techniques which need further researches to establish protocols to use them clinically with conviction.
\end{abstract}

\section{Introduction}

The major concern of most of the patients going for orthodontic treatment is to improve their dentofacial esthetics while oral health benefits are secondary concerns [1] However like other interventions orthodontic treatment with fixed appliances also poses some inherent complications and risks. These undesirable outcomes of the treatment are either due to excessive force exerted on the tooth in order to achieve movement or with difficulty in brushing and plaque accumulation around brackets $[2,3]$. Irrespective of the reason, adverse effects of treatment are directly proportionate to the duration of treatment. Currently the duration of orthodontic treatment with fixed braces is 2 to 3 years on average $[4,5]$; however the patient does not want more than
1.5 years [6]. Prolonged treatment duration is also detrimental to the productivity of a national healthcare system and private practices [7]; therefore accelerating the tooth movement and shortening the treatment duration have always been an issue of concern for patients as well as for orthodontists [8].

There are two basic ways to reduce the treatment duration (Table 1). One approach is by making the treatment mechanics more efficient, for example, use of low friction and selfligating brackets $[9,10]$, preformed robotic archwires [11, 12], and use of microimplants $[13,14]$.

Another approach involves interventions to increase the velocity of orthodontic tooth movement by enhancing the bone remodeling. This intervention can be classified into three categories: (1) use of certain biochemical, (2) mechanical or physical stimulation of the alveolar bone which 
TABLE 1: Methods to reduce orthodontic treatment duration.

\begin{tabular}{|c|c|}
\hline $\begin{array}{l}\text { More efficient } \\
\text { mechanics }\end{array}$ & $\begin{array}{l}\text { (i) Low friction mechanics } \\
\text { (ii) Self-ligating brackets } \\
\text { (iii) Preformed robotic archwires } \\
\text { (iv) Microimplants }\end{array}$ \\
\hline $\begin{array}{l}\text { Enhance bone } \\
\text { remodeling }\end{array}$ & $\begin{array}{l}\text { (i) Biochemical } \\
\text { (ii) Parathyroid hormone } \\
\text { (iii) Parathyroid hormone } \\
\text { (iv) Osteocalcin } \\
\text { (v) Dihydroxyvitamin D3 (1,25-(OH)2D3) }\end{array}$ \\
\hline $\begin{array}{l}\text { Physical } \\
\text { stimulation }\end{array}$ & $\begin{array}{l}\text { (i) Micropulse and cyclic vibration } \\
\text { (ii) Low level laser therapy } \\
\text { (iii) Low intensity pulsed ultrasound }\end{array}$ \\
\hline $\begin{array}{l}\text { Surgical } \\
\text { approach }\end{array}$ & $\begin{array}{l}\text { (i) Corticotomy } \\
\text { (ii) Periodontally assisted osteogenic orthodontics } \\
\text { (iii) Piezocision assisted orthodontics }\end{array}$ \\
\hline
\end{tabular}

includes the use of cyclic vibration [15], magnets [16], or direct electrical current [16], and (3) surgical interventions to accelerate tooth movement [17].

Local administration of biochemical such as dihydroxyvitamin D3 (1,25-(OH)2D3) [18], parathyroid hormone [19], prostaglandin E2 (PGE2) [20], or osteocalcin [21] has systematic effects on body metabolism; therefore they are difficult to use for orthodontic tooth movement. Electric and pulsed electromagnetic field has no convincing evidence to be an effective modality for rapid movement [22].

Surgical procedures that enhance tooth movement involve alveolar corticotomies, rapid canine retraction, or dental distraction. These are highly invasive procedures associated with postoperative morbidity and harmful effects on periodontal tissues; thus the patient's acceptance of the procedure is low [23].

Hence the researchers are always looking for minimally invasive methods that enhance the orthodontic tooth movement and are also well accepted by the patients because of minimal side effects and low cost. Low level laser therapy [24] has shown some evidence of being effective in acceleration of tooth movement in humans and also been reviewed systematically [25]. However the need is to bring the researcher's attention towards all other techniques used in animal based researches on the subject so that there is further progress in the development of minimally invasive/noninvasive techniques. Therefore the objective of this systematic review is to review all recently published animal studies involving noninvasive as well as minimally invasive procedures for acceleration of orthodontic tooth movement.

\section{Materials and Methods}

2.1. Eligibility Criteria. Publications included in this study comprised research articles from the past six years, that is, from January 2009 till 31 December 2014. Eligibility criteria for inclusion were original in vivo researches on the noninvasive/minimally invasive modalities to enhance orthodontic tooth movement in animals. Randomized clinical trials and human based researches were excluded from the systematic review. Articles dealing with role of biochemical
TABLE 2: Inclusion and exclusion criteria for the systematic review.

\begin{tabular}{ll}
\hline Inclusion criteria & Exclusion criteria \\
\hline Original research articles & Randomized clinical trials \\
referring to noninvasive & $\begin{array}{l}\text { Articles dealing with highly invasive } \\
\text { procedures }\end{array}$ \\
modalities or minimally & Articles referring to use of biochemical \\
invasive techniques to & or drugs to accelerate tooth movement \\
accelerate orthodontic & Microimplants or frictionless brackets \\
tooth movement & $\begin{array}{l}\text { as a modality to reduce treatment } \\
\text { duration }\end{array}$ \\
Animal studies & Reviews, interviews, and discussions \\
\hline
\end{tabular}

and cytokines were excluded from the study. Highly invasive procedures like Wilckodontics and periodontally assisted orthodontics were also excluded from this systematic review (Table 2).

2.2. Information Resources and Search Strategy. Electronic database was searched in this study with related keyword combinations, using three main search engines to track down the articles.

Electronic databases searched are as follows:

(i) NCBI databases:

PubMed.

PubMed Central.

PubMed Health.

(ii) MedPilot:

Medline.

Catalogue ZB MED.

Catalogue Medicine Health.

Excerpta Medica Database (EMBASE).

(iii) Google Scholar.

The main keyword used to search the literature was "orthodontic tooth movement", which was searched in combination with the following terms:

(i) Concerning enhancement of movement: accelerate, rapid, velocity.

(ii) Concerning invasiveness: minimally invasive, non invasive.

2.3. Data Extraction and Quality Assessment. Two authors independently searched the literature, selected the studies, extracted the data, and assessed the risk of bias of the studies using ARRIVE (Animal Research: Reporting of In Vivo Experiments) guidelines [26]. Interobserver disagreements were resolved with discussions. The quality assessment of the included studies was performed by using ARRIVE guidelines [26]. Maximum score of 20 was attributed to each study. Studies were evaluated and categorized as good $(\geq 75 \%)$, moderate $(56 \%$ to $74 \%)$, or poor $(\leq 55 \%)$ quality based on the total score attained (Table 3). 


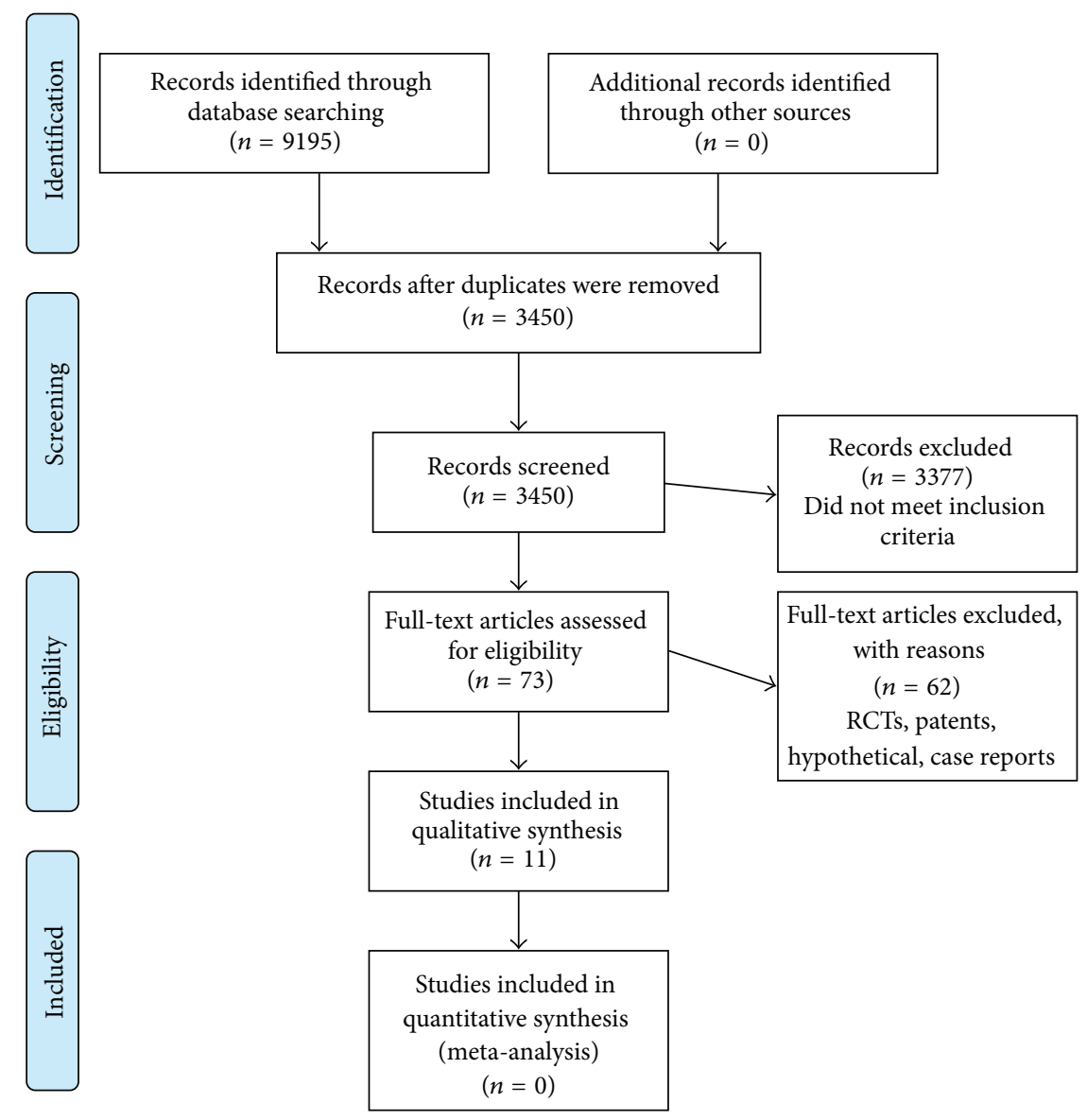

FIGURE 1: PRISMA 2009 flow diagram. From [60]. For more information, visit http://www.prisma-statement.org/.

TABLE 3: Quality assessment scores of selected studies.

\begin{tabular}{lccc}
\hline Procedure & $\begin{array}{c}\text { Good } \\
\geq 75 \%\end{array}$ & $\begin{array}{c}\text { Moderate } \\
56 \% \text { to } 74 \%\end{array}$ & $\begin{array}{c}\text { Poor } \\
\leq 55 \%\end{array}$ \\
\hline Minimally invasive [5] & 4 & 1 & \\
Noninvasive [5] & 4 & 1 & \\
Combination [1] & 1 & & \\
& 9 & 2 & \\
\hline
\end{tabular}

2.4. Statistical Analysis. Cohen's kappa analysis was performed to assess the interobserver agreement to grade the quality of the studies, using SPSS version 20. The level of agreement was evaluated by Landis and Koch criteria [27]. Interrater agreement is near to perfect if the value of kappa is $0.81-1$, substantial if kappa is $0.61-0.80$, moderate if kappa is $0.41-0.60$, fair if kappa is $0.21-0.40$, and poor if kappa is less than 0.20 .

\section{Results}

3.1. Study Selection. PRISMA guidelines were followed to scrutinize the articles as detailed in Table 4 and Figure 1. The total number of hits was 9195 in the databases: 8873 in Google Scholar, 43 in MedPilot, and 279 in NCBI search resources. After adjusting the duplicates, 3450 hits were scrutinized for inclusion in the study. The majority of them were excluded as they did not match the inclusion criteria, leaving 73 publications. After excluding randomized clinical trials, patents, case reports, and hypothetical articles, just 11 original articles were remained which were included in this systematic review.

Interobserver reliability for 20 criteria was 0.54 which is a moderate level of agreement. Cohen's kappa for the majority of the criteria from $\mathrm{A}$ to $\mathrm{T}$ showed absolute agreement except four criteria which showed moderate-to-good level of interrater agreement: $\mathrm{A}=1, \mathrm{~B}=0.45, \mathrm{C}=1, \mathrm{D}=0.76$, $\mathrm{E}=0.58, \mathrm{~F}=0.88, \mathrm{G}=0.88, \mathrm{H}=1, \mathrm{I}=0.76, \mathrm{~J}=0.87$, $\mathrm{K}=1, \mathrm{~L}=1, \mathrm{M}=0.83, \mathrm{~N}=0.90, \mathrm{O}=0.86, \mathrm{P}=0.94, \mathrm{Q}=1$, $\mathrm{R}=0.82, \mathrm{~S}=0.92$, and $\mathrm{T}=0.90$.

3.2. Study Characteristics. The selected articles could be categorized in two major categories: (A) studies focusing on noninvasive modalities and (B) studies involving minimally invasive modalities. Noninvasive procedures included 5 articles and studies based on minimally invasive techniques were 5 . One article combined both invasive and noninvasive procedure to enhance orthodontic tooth movement.

In noninvasive modalities 2 researches were based on the use of low level laser therapy (LLLT) for acceleration of 
TABLE 4: PRISMA 2009 Checklist.

\begin{tabular}{|c|c|c|c|}
\hline Section/topic & \# & Checklist item & $\begin{array}{l}\text { Reported on } \\
\text { page \# }\end{array}$ \\
\hline \multicolumn{4}{|l|}{ Title } \\
\hline Title & 1 & Identify the report as a systematic review, meta-analysis, or both & 1 \\
\hline \multicolumn{4}{|c|}{ 然 1} \\
\hline Structured summary & 2 & $\begin{array}{l}\text { Provide a structured summary including, as applicable, background; objectives; data } \\
\text { sources; study eligibility criteria, participants, and interventions; study appraisal and } \\
\text { synthesis methods; results; limitations; conclusions and implications of key findings; } \\
\text { systematic review registration number }\end{array}$ & 1 \\
\hline \multicolumn{4}{|l|}{ Introduction } \\
\hline Rationale & 3 & Describe the rationale for the review in the context of what is already known & 3 \\
\hline Objectives & 4 & $\begin{array}{l}\text { Provide an explicit statement of questions being addressed with reference to } \\
\text { participants, interventions, comparisons, outcomes, and study design (PICOS) }\end{array}$ & 3 \\
\hline \multicolumn{4}{|c|}{1} \\
\hline Protocol and registration & 5 & $\begin{array}{l}\text { Indicate if a review protocol exists and if and where it can be accessed (e.g., Web } \\
\text { address) and if available provide registration information including registration } \\
\text { number }\end{array}$ & \\
\hline Eligibility criteria & 6 & $\begin{array}{l}\text { Specify study characteristics (e.g., PICOS, length of follow-up) and report } \\
\text { characteristics (e.g., years considered, language, and publication status) used as } \\
\text { criteria for eligibility, giving rationale }\end{array}$ & 3 \\
\hline Information sources & 7 & $\begin{array}{l}\text { Describe all information sources (e.g., databases with dates of coverage, contact with } \\
\text { study authors to identify additional studies) in the search and date last searched }\end{array}$ & 3 \\
\hline Search & 8 & $\begin{array}{l}\text { Present full electronic search strategy for at least one database, including any limits } \\
\text { used, such that it could be repeated }\end{array}$ & 4 \\
\hline Study selection & 9 & $\begin{array}{l}\text { State the process for selecting studies (i.e., screening, eligibility, included in } \\
\text { systematic review and if applicable included in the meta-analysis) }\end{array}$ & 4 \\
\hline Data collection process & 10 & $\begin{array}{l}\text { Describe method of data extraction from reports (e.g., piloted forms, independently, } \\
\text { in duplicate) and any processes for obtaining and confirming data from investigators }\end{array}$ & 4 \\
\hline Data items & 11 & $\begin{array}{l}\text { List and define all variables for which data were sought (e.g., PICOS, funding } \\
\text { sources) and any assumptions and simplifications made }\end{array}$ & \\
\hline Risk of bias in individual studi & & $\begin{array}{l}\text { Describe methods used for assessing risk of bias of individual studies (including } \\
\text { specification of whether this was done at the study or outcome level) and how this } \\
\text { information is to be used in any data synthesis }\end{array}$ & 4 \\
\hline Summary measures & 13 & State the principal summary measures (e.g., risk ratio, difference in means) & \\
\hline Synthesis of results & 14 & $\begin{array}{l}\text { Describe the methods of handling data and combining results of studies, if done, } \\
\left.\text { including measures of consistency (e.g., } I^{2}\right) \text { for each meta-analysis }\end{array}$ & \\
\hline Risk of bias across studies & 15 & $\begin{array}{l}\text { Specify any assessment of risk of bias that may affect the cumulative evidence (e.g., } \\
\text { publication bias, selective reporting within studies) }\end{array}$ & 4 \\
\hline Additional analyses & 16 & $\begin{array}{l}\text { Describe methods of additional analyses (e.g., sensitivity or subgroup analyses, } \\
\text { metaregression), if done, indicating which were prespecified }\end{array}$ & 4 \\
\hline \multicolumn{4}{|l|}{ Results } \\
\hline Study selection & 17 & $\begin{array}{l}\text { Give numbers of studies screened, assessed for eligibility, and included in the review, } \\
\text { with reasons for exclusions at each stage, ideally with a flow diagram }\end{array}$ & 5 \\
\hline Study characteristics & 18 & $\begin{array}{l}\text { For each study, present characteristics for which data were extracted (e.g., study size, } \\
\text { PICOS, and follow-up period) and provide the citations }\end{array}$ & \\
\hline Risk of bias within studies & 19 & $\begin{array}{l}\text { Present data on risk of bias of each study and if available any outcome level } \\
\text { assessment (see item 12) }\end{array}$ & 6 \\
\hline Results of individual studies & 20 & $\begin{array}{l}\text { For all outcomes considered (benefits or harms), present, for each study: (a) simple } \\
\text { summary data for each intervention group, (b) effect estimates and confidence } \\
\text { intervals, ideally with a forest plot }\end{array}$ & \\
\hline Synthesis of results & 21 & $\begin{array}{l}\text { Present results of each meta-analysis done, including confidence intervals and } \\
\text { measures of consistency }\end{array}$ & \\
\hline Risk of bias across studies & 22 & Present results of any assessment of risk of bias across studies (see item 15) & 6 \\
\hline Additional analysis & 23 & $\begin{array}{l}\text { Give results of additional analyses, if done (e.g., sensitivity or subgroup analyses, } \\
\text { metaregression [see item 16]) }\end{array}$ & \\
\hline
\end{tabular}


TABLE 4: Continued.

\begin{tabular}{|c|c|c|c|}
\hline Section/topic & $\#$ & Checklist item & $\begin{array}{l}\text { Reported on } \\
\text { page \# }\end{array}$ \\
\hline \multicolumn{4}{|l|}{ Discussion } \\
\hline Summary of evidence & 24 & $\begin{array}{l}\text { Summarize the main findings including the strength of evidence for each main } \\
\text { outcome; consider their relevance to key groups (e.g., healthcare providers, users, } \\
\text { and policy makers) }\end{array}$ & $6-10$ \\
\hline Limitations & 25 & $\begin{array}{l}\text { Discuss limitations at study and outcome level (e.g., risk of bias) and at review-level } \\
\text { (e.g., incomplete retrieval of identified research, reporting bias) }\end{array}$ & \\
\hline Conclusions & 26 & $\begin{array}{l}\text { Provide a general interpretation of the results in the context of other evidence and } \\
\text { implications for future research }\end{array}$ & 10 \\
\hline \multicolumn{4}{|l|}{ Funding } \\
\hline Funding & 27 & $\begin{array}{l}\text { Describe sources of funding for the systematic review and other support (e.g., supply } \\
\text { of data); role of funders for the systematic review }\end{array}$ & Nil \\
\hline
\end{tabular}

From [60]. For more information, visit: http://www.prisma-statement.org/.

TABLE 5: Assessment of the included studies based on quality assessment tool.

\begin{tabular}{|c|c|c|c|c|c|c|c|c|c|c|c|c|c|c|c|c|c|c|c|c|c|c|c|}
\hline Author & Year & Topic & 1 & 2 & 3 & 4 & 5 & 6 & 7 & 8 & 9 & 10 & 11 & 12 & 13 & 14 & 15 & 16 & 17 & 18 & 19 & 20 & Score \\
\hline Altan et al. [40] & 2012 & LLLT & $\checkmark$ & $\checkmark$ & $\checkmark$ & $\checkmark$ & $\checkmark$ & $\checkmark$ & $\checkmark$ & $\checkmark$ & $\checkmark$ & $\begin{array}{l} \\
x\end{array}$ & $\checkmark$ & $\checkmark$ & $\begin{array}{l}r \\
x\end{array}$ & $r$ & $\checkmark$ & $x$ & $x$ & $\begin{array}{l}r \\
x\end{array}$ & $\begin{array}{l}r \\
x\end{array}$ & $\checkmark$ & 16 \\
\hline Shirazi et al. [39] & 2013 & LLLT & $\checkmark$ & $\checkmark$ & $\checkmark$ & $\checkmark$ & $\checkmark$ & $\checkmark$ & $\checkmark$ & $\checkmark$ & $\checkmark$ & $\begin{array}{l}r \\
x\end{array}$ & $\begin{array}{l}r \\
x\end{array}$ & $\checkmark$ & $\checkmark$ & $r$ & $\checkmark$ & $r$ & $x$ & $\checkmark$ & $\checkmark$ & $x$ & 17 \\
\hline Xue et al. [45] & 2013 & LIPUS & $\checkmark$ & $\checkmark$ & $\checkmark$ & $\checkmark$ & $\checkmark$ & $\checkmark$ & $\checkmark$ & & $\checkmark$ & $\begin{array}{l}r \\
x\end{array}$ & $\begin{array}{l}r \\
x\end{array}$ & $\checkmark$ & $\checkmark$ & $\checkmark$ & $\checkmark$ & $r$ & $\begin{array}{l}r \\
x\end{array}$ & $\begin{array}{l}r \\
x\end{array}$ & $x$ & $\checkmark$ & 17 \\
\hline $\begin{array}{l}\text { Al-Daghreer et } \\
\text { al. [46] }\end{array}$ & 2014 & LIPUS & $\checkmark$ & $\checkmark$ & $\checkmark$ & $\checkmark$ & $\checkmark$ & $\checkmark$ & $\checkmark$ & $x$ & $x$ & $\begin{array}{l}r \\
x\end{array}$ & $\checkmark$ & $\checkmark$ & $\checkmark$ & $x$ & $\checkmark$ & $\begin{array}{l}r \\
x\end{array}$ & $x$ & $\checkmark$ & $r$ & $\checkmark$ & 15 \\
\hline $\begin{array}{l}\text { AlSayagh and } \\
\text { Salman [50] }\end{array}$ & 2014 & $\begin{array}{l}\text { Mechanical } \\
\text { vibration }\end{array}$ & $\checkmark$ & $x$ & $\checkmark$ & $x$ & $x$ & $\checkmark$ & $\checkmark$ & $x$ & $\checkmark$ & $\begin{array}{l}r \\
x\end{array}$ & $x$ & $x$ & $\checkmark$ & $r$ & $\checkmark$ & $x$ & $x$ & $\checkmark$ & $\checkmark$ & $x$ & 10 \\
\hline Kim et al. [42] & 2009 & $\begin{array}{l}\text { LLLT and } \\
\text { corticision }\end{array}$ & $\checkmark$ & $\checkmark$ & $\checkmark$ & $\checkmark$ & $x$ & $\checkmark$ & $\checkmark$ & $\checkmark$ & $\checkmark$ & $\begin{array}{l}r \\
x\end{array}$ & $\checkmark$ & $\checkmark$ & $\checkmark$ & $r$ & $\checkmark$ & $\checkmark$ & $x$ & $\checkmark$ & $\checkmark$ & $\checkmark$ & 18 \\
\hline Seifi et al. [58] & 2012 & $\begin{array}{l}\text { Laser assisted } \\
\text { flapless } \\
\text { corticotomy }\end{array}$ & $\checkmark$ & $\checkmark$ & $\checkmark$ & $\checkmark$ & $x$ & $\begin{array}{l}\gamma \\
x\end{array}$ & $\checkmark$ & $x$ & $x$ & $\begin{array}{l}r \\
x\end{array}$ & $x$ & $\checkmark$ & $x$ & $x$ & $\checkmark$ & $x$ & $\checkmark$ & $\checkmark$ & $r$ & $x$ & 11 \\
\hline Kim et al. [61] & 2013 & Piezopuncture & $\checkmark$ & $\checkmark$ & $\checkmark$ & $\checkmark$ & $x$ & $\checkmark$ & $\begin{array}{l}r \\
x\end{array}$ & $r$ & $\checkmark$ & $\begin{array}{l}r \\
x\end{array}$ & $\checkmark$ & $\checkmark$ & $\checkmark$ & $r$ & $\checkmark$ & $\begin{array}{l}r \\
x\end{array}$ & $x$ & $\begin{array}{l}r \\
x\end{array}$ & $r$ & $\checkmark$ & 16 \\
\hline Safavi et al. [59] & 2012 & $\begin{array}{l}\text { Flapless bur } \\
\text { decortication }\end{array}$ & $\checkmark$ & $\begin{array}{l}r \\
x\end{array}$ & $\checkmark$ & $\checkmark$ & $x$ & $\checkmark$ & $\checkmark$ & $\checkmark$ & $x$ & $\begin{array}{l}r \\
x\end{array}$ & $x$ & $x$ & $\checkmark$ & $r$ & $r$ & $r$ & $\checkmark$ & $r$ & $\checkmark$ & $\checkmark$ & 15 \\
\hline Dibart et al. [55] & 2013 & Piezocision & $\checkmark$ & $\checkmark$ & $\checkmark$ & $x$ & $\checkmark$ & $\checkmark$ & $\checkmark$ & $\checkmark$ & $x$ & $\begin{array}{l}r \\
x\end{array}$ & $x$ & $\checkmark$ & $x$ & $r$ & $r$ & $\begin{array}{l}r \\
x\end{array}$ & $r$ & $\checkmark$ & $r$ & $\checkmark$ & 15 \\
\hline Ruso et al. [56] & 2013 & $\begin{array}{c}\text { Flapless } \\
\text { decortication }\end{array}$ & $\checkmark$ & $\begin{array}{l}r \\
x\end{array}$ & $\checkmark$ & $\checkmark$ & $\checkmark$ & $\checkmark$ & $\checkmark$ & $r$ & $x$ & $\begin{array}{l}r \\
x \\
\end{array}$ & $r$ & $r$ & $r$ & $r$ & $\checkmark$ & $r$ & $\checkmark$ & $r$ & $r$ & $\checkmark$ & 18 \\
\hline
\end{tabular}

orthodontic tooth movement, 1 article evaluated mechanical vibration, and 2 involved low intensity pulsed ultrasound (LIPUS). One article studied the effect of LLLT with piezocision on velocity of tooth movement in animal model.

In minimally invasive group, all researches involved flapless corticision with slightly different approaches. Three researchers used piezoelectric knife, 1 author used laser assisted corticision, and 1 research evaluated flapless corticotomy using burs.

3.3. Quality Assessment and Risk of Bias. The quality of the studies was assessed by ARRIVE guidelines. Table 5 shows the assessment of the included studies. The quality of most of the studies was good and none of the studies were categorized as poor quality (Table 3). Low level laser therapy was the most common among noninvasive modalities ( 2 articles) as it was also used along with corticision in an article. However flapless piezocision was among the commonest minimally invasive procedures to enhance orthodontic tooth movement (3 studies).

\section{Discussion}

\subsection{Noninvasive Techniques}

4.1.1. Low Level Laser Therapy. Low level laser therapy (LLLT) is also known as photobiomodulation or biostimulation that involves the use of near infrared or low levels of red light 
TABLE 6: Use of LLLT to accelerate orthodontic tooth movement in animals.

\begin{tabular}{|c|c|c|c|c|c|c|}
\hline Author name & Sample & Laser type & Energy & Results & $\begin{array}{l}\text { Movement in } \\
\text { experimental } \\
\text { group }(\mathrm{mm})\end{array}$ & $\begin{array}{l}\text { Movement in } \\
\text { control group } \\
(\mathrm{mm})\end{array}$ \\
\hline Shirazi et al. [39] & $\begin{array}{c}30 \text { rats divided into } 2 \\
\text { groups, } 15 \text { each }\end{array}$ & $\begin{array}{l}\text { GaAlP diode } \\
660 \mathrm{~nm} \\
\text { Continuous } \\
\text { wave mode } \\
25 \mathrm{~mW} \\
660 \mathrm{~nm}\end{array}$ & $\begin{array}{c}7.5 \mathrm{~J} / \mathrm{session} \\
5 \mathrm{~min} / \mathrm{session} \text { after } \\
\text { every } 48 \mathrm{hrs} \\
\text { for a total of } 6 \\
\text { sessions }\end{array}$ & $\begin{array}{c}\text { 2.3-fold acceleration in tooth } \\
\text { movement in laser irradiated } \\
\text { group }\end{array}$ & $\begin{array}{l}0.39 \pm 0.07 \\
P<0.001\end{array}$ & $0.11 \pm 0.04$ \\
\hline Altan et al. [40] & $\begin{array}{l}38 \text { male Wistar rats } \\
\text { divided into } 4 \text { groups: } \\
3 \text { experimental groups } \\
=11 \text { rats each, } 1 \\
\text { control group }=5 \text { rats }\end{array}$ & $\begin{array}{c}\text { GaAlAs } \\
820 \mathrm{~nm} \\
\text { Continuous } \\
\text { mode } 100 \mathrm{~mW}\end{array}$ & $\begin{array}{c}\text { One group } \\
\text { received } \\
54 \mathrm{~J} / \text { session } \\
\text { The other group } \\
\text { received } \\
15 \mathrm{~J} / \text { session applied } \\
\text { daily for } 8 \text { days }\end{array}$ & $\begin{array}{c}\text { No statistically significant } \\
\text { result }\end{array}$ & $\begin{array}{l}\text { Not } \\
\text { mentioned }\end{array}$ & $\begin{array}{l}\text { Not } \\
\text { mentioned }\end{array}$ \\
\hline $\begin{array}{l}\text { Kim et al. [42] } \\
\text { (combination } \\
\text { with corticision) }\end{array}$ & $\begin{array}{l}12 \text { beagle dogs } \\
\text { Maxillary } 2 \text { nd } \\
\text { premolars }(n=24) \\
\text { divided into } 4 \text { groups } \\
\quad(n=6) \\
\text { Split mouth design }\end{array}$ & $\begin{array}{l}\text { GaAlAs } \\
808 \mathrm{~nm} \\
\text { Pulsed mode } \\
763 \mathrm{~mW}\end{array}$ & $\begin{array}{c}75 \mathrm{~mJ} \text { per pulse } \\
41.7 \mathrm{~J} / \mathrm{cm}^{2} / \text { point } \\
333.6 \mathrm{~J} / \mathrm{cm}^{2} / \text { session } \\
\text { Applied every } 3 \mathrm{rd} \\
\text { day for } 8 \text { weeks }\end{array}$ & $\begin{array}{l}\text { LLLT accelerated tooth } \\
\text { movement } 3.75 \text {-fold } \\
\text { Corticision accelerated tooth } \\
\text { movement } 3.76 \text {-fold } \\
\text { No significant difference in } \\
\text { tooth movement in LLLT + } \\
\quad \text { corticision group }\end{array}$ & $\begin{array}{l}4.62 \pm 0.25 \\
P<0.001 \\
4.61 \pm 0.30 \\
P<0.001 \\
0.88 \pm 0.19 \\
P<0.001\end{array}$ & $0.23 \pm 0.18$ \\
\hline
\end{tabular}

to treat a variety of ailments. It does not raise local tissue temperature by more than $1^{\circ} \mathrm{C}$ and therefore is referred to as "cold laser" or "low level laser" $[8,28]$. Although the exact mechanism of therapeutic effects of LLLT is not well established yet, it has been observed that it has effects at the molecular, cellular, and tissue levels. At the cellular level, there is strong evidence that LLLT acts on mitochondria [29] which results in increase in adenosine triphosphate (ATP) production [30] and the induction of transcription factors [31]. These transcription factors trigger protein synthesis leading to cell proliferation and migration. It also modulates the levels of cytokines, inflammatory mediators, and growth factors [32]. Since LLLT accelerate bone regeneration and remodeling by increasing vascularization, promoting trabecular osteoid tissue formation, and enhancing tissue metabolism [33], therefore it was thought to be beneficial also in acceleration of orthodontic tooth movement.

In vitro studies involving rat osteoclast precursor cells and osteoclasts have shown that laser irradiation induces differentiation and activation of osteoclasts [34-38] through expression of RANK, MMP-9, cathepsin K, and $\alpha$ (v) $\beta 3$ integrin.

In all of the articles included in this systematic review, diode laser was the source of LLLT including the one which combined LLLT with corticision; however the wavelength, frequency, energy input, and hence the results were slightly different (Table 6) $[39,40]$. Shirazi et al. [39] in their research concluded that LLLT can increase the velocity of tooth movement 2.3-fold and the laser light does not reflect to the contralateral side as they found no difference in the movement on the contralateral side compared with the control group. However Altan et al. [40] reported no difference between laser and control groups after application of high energy density. The reason for insignificant results could be the use of higher energy density (54J) used by Altan in his study, because the most effective range of LLLT for biomodulation is reported to be $0.5-4 \mathrm{~J} / \mathrm{cm}^{2}$ [41].

Kim et al. applied high energy density laser therapy and found it equally effective in accelerating tooth movement as corticision [42]. But the difference in their research from other reviewed articles was the pulsed mode of laser therapy rather than the continuous mode. When both the procedures (LLLT and corticision) were performed on the same site, there was decrease in the velocity of tooth movement. Although the article was good in quality assessment, the sample size ( $n=6$ premolars in each group) was too small to reach any conclusion.

4.1.2. Low Intensity Pulsed Ultrasound. Ultrasound is a sound wave having frequency above the limit of human ear perception, which can be transmitted into biological tissues. It is widely used in the field of medicine for diagnostic as well as therapeutic purpose [43]. LIPUS stimulation is being utilized effectively as therapeutic modality for bone regeneration and fracture healing; therefore it has been approved by the U.S. Food and Drug Administration (FDA) for healing of fractured bone [8].

Although very limited studies have been conducted on the effects of LIPUS on tooth movement, in vitro studies have shown that LIPUS has anabolic effects on growth factors and other signaling factors production that results in differentiation of osteogenic cells and extracellular matrix [44]. In a very recent study involving rat model, LIPUS accelerated orthodontic tooth movement by $45 \%$ and promoted alveolar bone remodeling by stimulating the HGF/Runx2/BMP-2 signaling pathway and RANKL expression [45]. 
TABLE 7: Use of low intensity pulsed ultrasound and mechanical vibrations to accelerate tooth movement in animals.

\begin{tabular}{|c|c|c|c|c|c|c|}
\hline Author & Sample & $\begin{array}{l}\text { LIPUS and } \\
\text { vibration } \\
\text { specification }\end{array}$ & Duration & Results & $\begin{array}{l}\text { Movement in } \\
\text { experimental } \\
\text { group }\end{array}$ & $\begin{array}{l}\text { Movement in } \\
\text { control group }\end{array}$ \\
\hline Xue et al. [45] & $\begin{array}{l}48 \text { rats } \\
\text { divided into } 6 \\
\text { groups }\end{array}$ & $\begin{array}{c}\text { Frequency } \\
\text { 1.5- } \mathrm{MHz} \text {; intensity } \\
30 \mathrm{~mW} / \mathrm{cm}^{2}\end{array}$ & $\begin{array}{c}\text { Burst of } 200 \mu \mathrm{s} \\
\text { followed by pause } \\
\text { of } 800 \mu \mathrm{s} \\
20 \mathrm{~min} / \text { day for } 14 \\
\text { days }\end{array}$ & $\begin{array}{c}55 \%, 36 \% \text {, and } 45 \% \\
\text { acceleration in tooth } \\
\text { movement on days } 5,7 \text {, and } \\
14 \text {, respectively }\end{array}$ & $\begin{array}{l}1118 \mu \mathrm{m} \pm \text { not } \\
\text { given }\end{array}$ & $\begin{array}{l}773 \pm \text { not } \\
\text { given }\end{array}$ \\
\hline $\begin{array}{l}\text { Al-Daghreer et } \\
\text { al. [46] }\end{array}$ & $\begin{array}{l}10 \text { beagle dogs } \\
\text { Split mouth design }\end{array}$ & $\begin{array}{c}\text { Frequency } \\
1.5 \mathrm{MHz} \text {; intensity } \\
30 \mathrm{~mW} / \mathrm{cm}^{2}\end{array}$ & $\begin{array}{c}200 \mu \mathrm{s} \\
20 \mathrm{~min} / \text { day for } \\
4 \text { weeks }\end{array}$ & $\begin{array}{c}\text { No significant difference in } \\
\text { the amount of tooth } \\
\text { movement }\end{array}$ & $\begin{array}{l}0.79 \mathrm{~mm} \pm \\
0.17 \\
P=0.05\end{array}$ & $0.6 \mathrm{~mm} \pm 0.21$ \\
\hline $\begin{array}{l}\text { AlSayagh and } \\
\text { Salman [50] }\end{array}$ & $\begin{array}{l}14 \text { rabbits divided } \\
\text { into } 2 \text { groups } \\
\quad(n=7)\end{array}$ & Frequency $113 \mathrm{~Hz}$ & $\begin{array}{c}1,3,5,8,10,12,15 \\
17, \text { and } 19 \text { days ( } 9 \\
\text { sessions of } 10 \mathrm{~min} \\
\text { each in } 22 \text { days) }\end{array}$ & $\begin{array}{l}\text { Acceleration in orthodontic } \\
\text { tooth movement }\end{array}$ & $\begin{array}{l}3.73 \mathrm{~mm} \pm \\
0.24\end{array}$ & $\begin{array}{l}3.11 \mathrm{~mm} \pm \\
0.07\end{array}$ \\
\hline
\end{tabular}

In this systematic review, 2 animal studies related to the role of LIPUS on orthodontic tooth movement were reviewed (Table 7). The outcome of both the researches was different in spite of using the same specification of LIPUS. Xue et al. reported $55 \%, 37 \%$, and $45 \%$ acceleration in tooth movement after application of LIPUS for 5, 7, and 14 days, respectively; however Al-Daghreer et al. found no difference in tooth movement even after application for 4 weeks $[45,46]$.

4.2. Mechanical Vibration. Low level mechanical vibration has profound effect on musculoskeletal morphology [47]. Mechanical vibration signals can promote bone healing, enhance bone strength, and reduce the negative effect of catabolic process [48]. It was hypothesized that mechanical vibration may reduce the lag phase (hyalinization) of orthodontic tooth movement and can result in painless and rapid movement [49].

In this review just 1 article in relation to the use of mechanical vibration for orthodontic tooth movement was reviewed [50]. Shirazi et al. [39] used animal model to assess the effect of mechanical vibration on incisor's movement and reported favorable results but because of vague methodology, indistinct selection criteria, and moderate quality scores, it was difficult for us to give remarks on the effect of mechanical vibration on orthodontic tooth movement.

4.3. Minimally Invasive Techniques. Osteotomy and corticotomy to accelerate tooth movement is not new in orthodontics, introduced by Köle in 1959 [51]. His concept was to segment the teeth containing alveolar bone with lingual and labial osteotomy and move the whole segmented alveolus with orthodontic forces. The technique was effective but required buccal as well as lingual full-thickness flaps followed by massive decortication of alveolar bone on buccal and lingual sides making the procedure very invasive and painful [52]. Thus the acceptance of the procedure was low and researchers were always looking for less invasive methods. Since the rapid movement in the procedure is not due to en bloc movement of alveolus rather there is a mechanism of accelerated soft tissue and hard tissue remodeling "Regional
Acceleratory Phenomenon (RAP)" associated directly with the severity of surgical procedure [53]. Osteoperforations placed even far from the tooth to be moved can increase the rate of tooth movement, by increasing the level of inflammatory cytokine expression and extensive osteoporotic changes [54]. This led to the incessant development of less invasive approaches.

In this systematic review, five animal studies in relation to the minimally invasive technique to accelerate orthodontic tooth movement were reviewed. Mucoperiosteal flap was not reflected in any of the researches and there was no massive decortication of cortical bone, which made the procedures less invasive. In two studies, piezosurgery unit was used to perform cuts on the buccal alveolar bone, mesial and distal to the tooth to be moved $[55,56]$. However Xue et al. used ultrasonic piezotome to create multiple holes buccally and lingually [45]. Since the velocity of tooth movement is in direct proportion to the amount of surgical insult, Ruso et al. [56] found acceleration only by $135 \%$ which was though significantly greater than the conventional group but lesser than the corticotomy induced acceleration reported earlier [57]. This was in accordance with the ultrasonic piezopuncture method used by Xue et al. [45] who suggested repeated application at regular intervals to overcome the deficient RAP phase associated. On the other hand Teixeira et al. [54] concluded that greater increase in velocity of tooth movement can be obtained if mechanical stimulation of alveolar bone is maintained through constant orthodontic force, along with piezosurgery. Seifi et al. [58] used Er,Cr;YSGG laser device with the energy range of $300 \mathrm{~mJ}$ and pulse rates of $20 \mathrm{~Hz}$ for corticotomy. They found twofold acceleration in tooth movement, without any adverse effects on periodontal health on the experimental side. Safavi et al. [59] used tungsten carbide bur in high torque slow speed surgical handpiece to make holes in the buccal cortical plate. They found accelerated tooth movement in the first month of the experiment followed by lesser amount of movement in the third month of experiment. The reason could be the formation of more mature lamellar bone after bur decortication as compared to the control group (Table 8). 
TABLE 8: Use of flapless corticotomy to accelerate orthodontic tooth movement in animals.

\begin{tabular}{|c|c|c|c|c|c|c|}
\hline Author & Sample & Procedure & Duration of study & Results & $\begin{array}{l}\text { Movement in } \\
\text { experimental } \\
\text { group }(\mathrm{mm})\end{array}$ & $\begin{array}{l}\text { Movement in } \\
\text { control group } \\
(\mathrm{mm})\end{array}$ \\
\hline Dibart et al. [55] & $\begin{array}{l}94 \text { Sprague Dawley } \\
\text { rats divided into } 4 \\
\text { groups: } \\
\text { control }=3 \text {, tooth } \\
\text { movement }=21, \\
\text { piezocision }=35, \text { and } \\
\text { piezocision }+ \text { tooth } \\
\text { movement }=35\end{array}$ & $\begin{array}{l}\text { Flapless } \\
\text { piezocision }\end{array}$ & 56 days & $\begin{array}{l}\text { Tooth movement accelerated } \\
\text { 2-fold }\end{array}$ & $\begin{array}{l}\text { Not } \\
\text { mentioned }\end{array}$ & $\begin{array}{l}\text { Not } \\
\text { mentioned }\end{array}$ \\
\hline Ruso et al. [56] & $\begin{array}{c}6 \text { dogs } \\
\text { Split mouth design }\end{array}$ & $\begin{array}{c}\text { Flapless } \\
\text { piezocision and } \\
\text { expansion with } \\
\text { archwire } \\
\end{array}$ & $\begin{array}{l}9 \text { weeks followed } \\
\text { by } 2 \text { weeks of } \\
\text { consolidation }\end{array}$ & $\begin{array}{l}\text { 135\% acceleration in tooth } \\
\text { movement }\end{array}$ & $\begin{array}{r}21.9 \pm 8.1^{\circ} \\
P<0.05\end{array}$ & $10.7 \pm 6^{\circ}$ \\
\hline Kim et al. [42] & $\begin{array}{c}10 \text { dogs } \\
\text { Control }(n=4) \\
\text { experimental }(n=6)\end{array}$ & $\begin{array}{c}\text { Flapless } \\
\text { piezopuncture }\end{array}$ & 6 weeks & $\begin{array}{l}\text { Tooth movement accelerated } \\
3.26-\text { and } 2.45 \text {-fold in maxilla } \\
\text { and mandible, respectively }\end{array}$ & $\begin{array}{l}2.31 \pm 0.82 \\
P<0.05 \\
1.33 \pm 0.28 \\
P<0.05\end{array}$ & $\begin{array}{l}0.72 \pm 0.06 \text { in } \\
\text { maxilla } \\
0.51 \pm 0.19 \text { in } \\
\text { mandible }\end{array}$ \\
\hline Safavi et al. [59] & $\begin{array}{c}5 \text { dogs } \\
\text { Split mouth design }\end{array}$ & $\begin{array}{l}\text { Flapless bur } \\
\text { decortication }\end{array}$ & 3 months & $\begin{array}{l}\text { No significant difference in } \\
\text { tooth movement }\end{array}$ & $\begin{array}{l}4.59 \pm 2.45 \\
P=0.063\end{array}$ & $4.88 \pm 1.93$ \\
\hline Seifi et al. [58] & $\begin{array}{l}8 \text { rabbits } \\
\text { Split mouth design }\end{array}$ & $\begin{array}{l}\text { Flapless } \\
\text { (Er-Cr:YSGG) } \\
\text { laserassisted } \\
\text { corticotomy }\end{array}$ & 21 days & $\begin{array}{l}\text { 1.77-fold acceleration in } \\
\text { tooth movement }\end{array}$ & $\begin{array}{l}1.65 \pm 0.34 \\
P=0.001\end{array}$ & $0.93 \pm 0.28$ \\
\hline
\end{tabular}

\section{Conclusion}

It can be concluded from the study that LLLT and flapless corticotomy have some evidence of accelerating effect on orthodontic tooth movement; however there is no set protocol found for the procedures yet. LIPUS and mechanical vibrations are also emerging noninvasive modalities but due to fewer studies, no evidence based conclusion can be drawn.

\section{Abbreviations}

LLLT: Low level laser therapy

LIPUS: Low intensity pulsed ultrasound.

\section{Conflict of Interests}

The authors declare that they have no competing interests.

\section{Authors' Contribution}

Irfan Qamruddin and Mohammad Khursheed Alam contributed equally.

\section{Acknowledgment}

This study was supported by USM RUI Grant 1001/PPSG/ 812154 .

\section{References}

[1] M. B. Ackerman, Enhancement Orthodontics: Theory and Practice, Wiley-Blackwell, 2007.

[2] N. F. Talic, "Adverse effects of orthodontic treatment: a clinical perspective," The Dental Journal, vol. 23, no. 2, pp. 55-59, 2011.

[3] P. Y.-W. Lau and R. W.-K. Wong, "Risks and complications in orthodontic treatment," Hong Kong Dental Journal, vol. 3, no. 1, pp. 15-22, 2006.

[4] D. F. Fink and R. J. Smith, "The duration of orthodontic treatment," American Journal of Orthodontics and Dentofacial Orthopedics, vol. 102, no. 1, pp. 45-51, 1992.

[5] M. A. Fisher, R. M. Wenger, and M. G. Hans, "Pretreatment characteristics associated with orthodontic treatment duration," American Journal of Orthodontics and Dentofacial Orthopedics, vol. 137, no. 2, pp. 178-186, 2010.

[6] M. S. Sayers and J. T. Newton, "Patients' expectations of orthodontic treatment: part 2-findings from a questionnaire survey," Journal of Orthodontics, vol. 34, no. 1, pp. 25-35, 2007.

[7] E. A. Turbill, S. Richmond, and J. L. Wright, "The time-factor in orthodontics: what influences the duration of treatments in National Health Service practices?" Community Dentistry and Oral Epidemiology, vol. 29, no. 1, pp. 62-72, 2001.

[8] M. M. Jawad, A. Husein, M. K. Alam, R. Hassan, and R. Shaari, "Overview of non-invasive factors (low level laser and low intensity pulsed ultrasound) accelerating tooth movement during orthodontic treatment," Lasers in Medical Science, vol. 29, no. 1, pp. 367-372, 2014.

[9] D. H. Damon, "The rationale, evolution and clinical application of the self-ligating bracket," Clinical Orthodontics and Research, vol. 1, no. 1, pp. 52-61, 1998. 
[10] A. Scribante, M.-F. Sfondrini, S. Gatti, and P. Gandini, "Disinclusion of unerupted teeth by mean of self-ligating brackets: effect of blood contamination on shear bond strength," Medicina Oral, Patologia Oral y Cirugia Bucal, vol. 18, no. 1, pp. e162e167, 2013.

[11] D. D. Oliveira, B. F. de Oliveira, and R. V. Soares, "Alveolar corticotomies in orthodontics: indications and effects on tooth movement," Dental Press Journal of Orthodontics, vol. 15, no. 4, pp. 144-157, 2010.

[12] R. Müller-Hartwich, T. M. Präger, and P.-G. Jost-Brinkmann, "SureSmile-CAD/CAM system for orthodontic treatment planning, simulation and fabrication of customized archwires," International Journal of Computerized Dentistry, vol. 10, no. 1, pp. 53-62, 2007.

[13] M. Motoyoshi, M. Matsuoka, and N. Shimizu, "Application of orthodontic mini-implants in adolescents," International Journal of Oral and Maxillofacial Surgery, vol. 36, no. 8, pp. 695699, 2007.

[14] J.-S. Kim, S.-M. Kang, K.-W. Seo et al., "Nanoscale bonding between human bone and titanium surfaces: osseohybridization," BioMed Research International, vol. 2015, Article ID 960410, 10 pages, 2015.

[15] C. H. Kau, "A radiographic analysis of tooth morphology following the use of a novel cyclical force device in orthodontics," Head \& Face Medicine, vol. 7, article 14, 2011.

[16] J. Kolahi, M. Abrishami, and Z. Davidovitch, "Microfabricated biocatalytic fuel cells: a new approach to accelerating the orthodontic tooth movement," Medical Hypotheses, vol. 73, no. 3, pp. 340-341, 2009.

[17] M. T. Wilcko, W. M. Wilcko, J. J. Pulver, N. F. Bissada, and J. E. Bouquot, "Accelerated osteogenic orthodontics technique: a 1-stage surgically facilitated rapid orthodontic technique with alveolar augmentation," Journal of Oral and Maxillofacial Surgery, vol. 67, no. 10, pp. 2149-2159, 2009.

[18] M. Kawakami and T. Takano-Yamamoto, "Local injection of 1,25-dihydroxyvitamin D3 enhanced bone formation for tooth stabilization after experimental tooth movement in rats," Journal of Bone and Mineral Metabolism, vol. 22, no. 6, pp. 541-546, 2004.

[19] S. Soma, M. Iwamoto, Y. Higuchi, and K. Kurisu, "Effects of continuous infusion of PTH on experimental tooth movement in rats," Journal of Bone and Mineral Research, vol. 14, no. 4, pp. 546-554, 1999.

[20] K. Yamasaki, Y. Shibata, and T. Fukuhara, "The effect of prostaglandins on experimental tooth movement in monkeys (Macaca fuscata)," Journal of Dental Research, vol. 61, no. 12, pp. 1444-1446, 1982.

[21] F. Hashimoto, Y. Kobayashi, S. Mataki, K. Kobayashi, Y. Kato, and H. Sakai, "Administration of osteocalcin accelerates orthodontic tooth movement induced by a closed coil spring in rats," The European Journal of Orthodontics, vol. 23, no. 5, pp. 535-545, 2001.

[22] H. Long, U. Pyakurel, Y. Wang, L. Liao, Y. Zhou, and W. Lai, "Interventions for accelerating orthodontic tooth movement: a systematic review," The Angle Orthodontist, vol. 83, no. 1, pp. 164-171, 2012.

[23] B. Gantes, E. Rathbun, and M. Anholm, "Effects on the periodontium following corticotomy-facilitated orthodontics. Case reports," Journal of Periodontology, vol. 61, no. 4, pp. 234238, 1990.

[24] M. K. Ge, W. L. He, J. Chen et al., "Efficacy of low-level laser therapy for accelerating tooth movement during orthodontic treatment: a systematic review and meta-analysis," Lasers in Medical Science, vol. 30, no. 5, pp. 1609-1618, 2015.

[25] N. Gkantidis, I. Mistakidis, T. Kouskoura, and N. Pandis, "Effectiveness of non-conventional methods for accelerated orthodontic tooth movement: a systematic review and metaanalysis," Journal of Dentistry, vol. 42, no. 10, pp. 1300-1319, 2014.

[26] C. Kilkenny, W. J. Browne, I. C. Cuthill, M. Emerson, and D. G. Altman, "Improving bioscience research reporting: the arrive guidelines for reporting animal research," PLoS Biology, vol. 8, no. 6, Article ID e1000412, 2010.

[27] J. R. Landis and G. G. Koch, "The measurement of observer agreement for categorical data," Biometrics, vol. 33, no. 1, pp. 159-174, 1977.

[28] H. Chung, T. Dai, S. K. Sharma, Y.-Y. Huang, J. D. Carroll, and M. R. Hamblin, "The nuts and bolts of low-level laser (light) therapy," Annals of Biomedical Engineering, vol. 40, no. 2, pp. 516-533, 2012.

[29] M. Greco, G. Guida, E. Perlino, E. Marra, and E. Quagliariello, "Increase in RNA and protein synthesis by mitochondria irradiated with helium-neon laser," Biochemical and Biophysical Research Communications, vol. 163, no. 3, pp. 1428-1434, 1989.

[30] T. Karu, "Primary and secondary mechanisms of action of visible to near-IR radiation on cells," Journal of Photochemistry and Photobiology B: Biology, vol. 49, no. 1, pp. 1-17, 1999.

[31] A. C.-H. Chen, P. R. Arany, Y.-Y. Huang et al., "Low-Level laser therapy activates NF-kB via generation of reactive oxygen species in mouse embryonic fibroblasts," PLoS ONE, vol. 6, no. 7, Article ID e22453, 2011.

[32] T. I. Karu and S. F. Kolyakov, "Exact action spectra for cellular responses relevant to phototherapy," Photomedicine and Laser Surgery, vol. 23, no. 4, pp. 355-361, 2005.

[33] S. E. Zahra, A. A. Elkasi, M. S. Eldin, and V. VandevskaRadunovic, "The effect of low level laser therapy (LLLT) on bone remodelling after median diastema closure: a one year and half follow-up study," Orthodontic Waves, vol. 68, no. 3, pp. 116-122, 2009.

[34] M. Yamaguchi, M. Hayashi, S. Fujita et al., "Low-energy laser irradiation facilitates the velocity of tooth movement and the expressions of matrix metalloproteinase-9, cathepsin $\mathrm{K}$, and alpha(v) beta(3) integrin in rats," The European Journal of Orthodontics, vol. 32, no. 2, pp. 131-139, 2010.

[35] S. Fujita, M. Yamaguchi, T. Utsunomiya, H. Yamamoto, and K. Kasai, "Low-energy laser stimulates tooth movement velocity via expression of RANK and RANKL," Orthodontics \& Craniofacial Research, vol. 11, no. 3, pp. 143-155, 2008.

[36] N. Aihara, M. Yamaguchi, and K. Kasai, "Low-energy irradiation stimulates formation of osteoclast-like cells via RANK expression in vitro," Lasers in Medical Science, vol. 21, no. 1, pp. 24-33, 2006.

[37] Y. Ueda and N. Shimizu, "Effects of pulse frequency of low-level laser therapy (LLLT) on bone nodule formation in rat calvarial cells," Journal of Clinical Laser Medicine \& Surgery, vol. 21, no. 5, pp. 271-277, 2003.

[38] M. M. Jawad, A. Husein, A. Azlina, M. K. Alam, R. Hassan, and R. Shaari, "Effect of $940 \mathrm{~nm}$ low-level laser therapy on osteogenesis in vitro," Journal of Biomedical Optics, vol. 18, no. 12, Article ID 128001, 2013.

[39] M. Shirazi, M. S. Ahmad Akhoundi, E. Javadi et al., "The effects of diode laser $(660 \mathrm{~nm})$ on the rate of tooth movements: an animal study," Lasers in Medical Science, vol. 30, no. 2, pp. 713718, 2013. 
[40] B. A. Altan, O. Sokucu, M. M. Ozkut, and S. Inan, "Metrical and histological investigation of the effects of low-level laser therapy on orthodontic tooth movement," Lasers in Medical Science, vol. 27, no. 1, pp. 131-140, 2012.

[41] E. Mester, A. F. Mester, and A. Mester, "The biomedical effects of laser application," Lasers in Surgery and Medicine, vol. 5, no. 1, pp. 31-39, 1985.

[42] S.-J. Kim, S.-U. Moon, S.-G. Kang, and Y.-G. Park, "Effects of low-level laser therapy after Corticision on tooth movement and paradental remodeling," Lasers in Surgery and Medicine, vol. 41, no. 7, pp. 524-533, 2009.

[43] E. Maylia and L. D. M. Nokes, "The use of ultrasonics in orthopaedics-a review," Technology and Health Care, vol. 7, no. 1, pp. 1-28, 1999.

[44] L. Claes and B. Willie, "The enhancement of bone regeneration by ultrasound," Progress in Biophysics and Molecular Biology, vol. 93, no. 1-3, pp. 384-398, 2007.

[45] H. Xue, J. Zheng, Z. Cui et al., "Low-intensity pulsed ultrasound accelerates tooth movement via activation of the BMP-2 signaling pathway," PLoS ONE, vol. 8, no. 7, Article ID e68926, 2013.

[46] S. Al-Daghreer, M. Doschak, A. J. Sloan et al., "Effect of lowintensity pulsed ultrasound on orthodontically induced root resorption in beagle dogs," Ultrasound in Medicine \& Biology, vol. 40, no. 6, pp. 1187-1196, 2014.

[47] C. Rubin, A. S. Turner, S. Bain, C. Mallinckrodt, and K. McLeod, "Anabolism: low mechanical signals strengthen long bones," Nature, vol. 412, no. 6847, pp. 603-604, 2001.

[48] L. Xie, C. Rubin, and S. Judex, "Enhancement of the adolescent murine musculoskeletal system using low-level mechanical vibrations," Journal of Applied Physiology, vol. 104, no. 4, pp. 1056-1062, 2008.

[49] J. A. Bosio and D. Liu, "Moving teeth faster, better and painless. Is it possible?" Dental Press Journal of Orthodontics, vol. 15, no. 6, pp. 14-17, 2010.

[50] N. M. AlSayagh and D. K. A. Salman, "The effect of mechanical vibration on the velocity of orthodontic tooth movement," International Journal of Enhanced Research in Science Technology \& Engineering, vol. 3, no. 1, pp. 284-291, 2014.

[51] H. Köle, "Surgical operations on the alveolar ridge to correct occlusal abnormalities," Oral Surgery, Oral Medicine, Oral Pathology, vol. 12, no. 5, pp. 515-529, 1959.

[52] S.-J. Kim, Y.-G. Park, and S.-G. Kang, "Effects of corticision on paradental remodeling in orthodontic tooth movement," The Angle Orthodontist, vol. 79, no. 2, pp. 284-291, 2008.

[53] H. M. Frost, "The regional acceleratory phenomenon: a review," Henry Ford Hospital Medical Journal, vol. 31, article 3, 1983.

[54] C. C. Teixeira, E. Khoo, J. Tran et al., "Cytokine expression and accelerated tooth movement," Journal of Dental Research, vol. 89, no. 10, pp. 1135-1141, 2010.

[55] S. Dibart, C. Yee, J. Surmenian et al., “Tissue response during Piezocision-assisted tooth movement: a histological study in rats," The European Journal of Orthodontics, vol. 36, no. 4, Article ID cjt079, pp. 457-464, 2013.

[56] S. Ruso, P. M. Campbell, J. Rossmann, L. A. Opperman, R. W. Taylor, and P. H. Buschang, "Bone response to buccal tooth movements-with and without flapless alveolar decortication," The European Journal of Orthodontics, vol. 36, no. 6, Article ID cjt057, pp. 613-623, 2013.

[57] Y. A. Mostafa, M. M. S. Fayed, S. Mehanni, N. N. ElBokle, and A. M. Heider, "Comparison of corticotomy-facilitated vs standard tooth-movement techniques in dogs with miniscrews as anchor units," American Journal of Orthodontics and Dentofacial Orthopedics, vol. 136, no. 4, pp. 570-577, 2009.

[58] M. Seifi, F. Younessian, and N. Ameli, "The innovated laser assisted flapless corticotomy to enhance orthodontic tooth movement," Journal of Lasers in Medical Sciences, vol. 3, no. 1, pp. 20-25, 2012.

[59] S. M. Safavi, M. Heidarpour, S. S. Izadi, and M. Heidarpour, "Effects of flapless bur decortications on movement velocity of dogs' teeth," Dental Research Journal, vol. 9, no. 6, pp. 783-789, 2012.

[60] D. Moher, A. Liberati, J. Tetzlaff, D. G. Altman, and The PRISMA Group, "Preferred reporting items for systematic reviews and meta-analyses: The PRISMA Statement," PLoS Medicine, vol. 6, no. 7, Article ID e1000097, 2009.

[61] Y.-S. Kim, S.-J. Kim, H.-J. Yoon, P.-J. Lee, W. Moon, and Y.-G. Park, "Effect of piezopuncture on tooth movement and bone remodeling in dogs," American Journal of Orthodontics and Dentofacial Orthopedics, vol. 144, no. 1, pp. 23-31, 2013. 

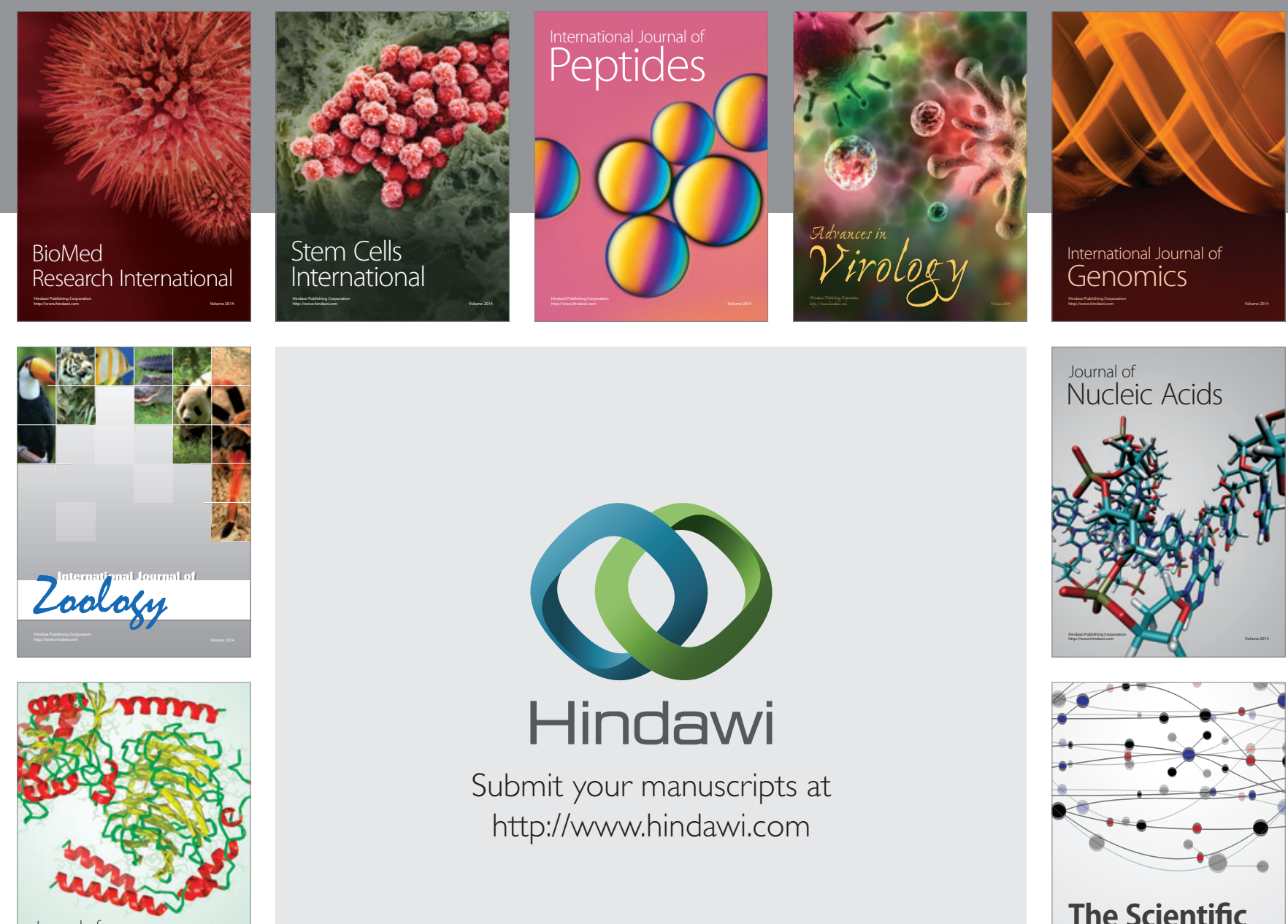

Submit your manuscripts at

http://www.hindawi.com

Journal of
Signal Transduction
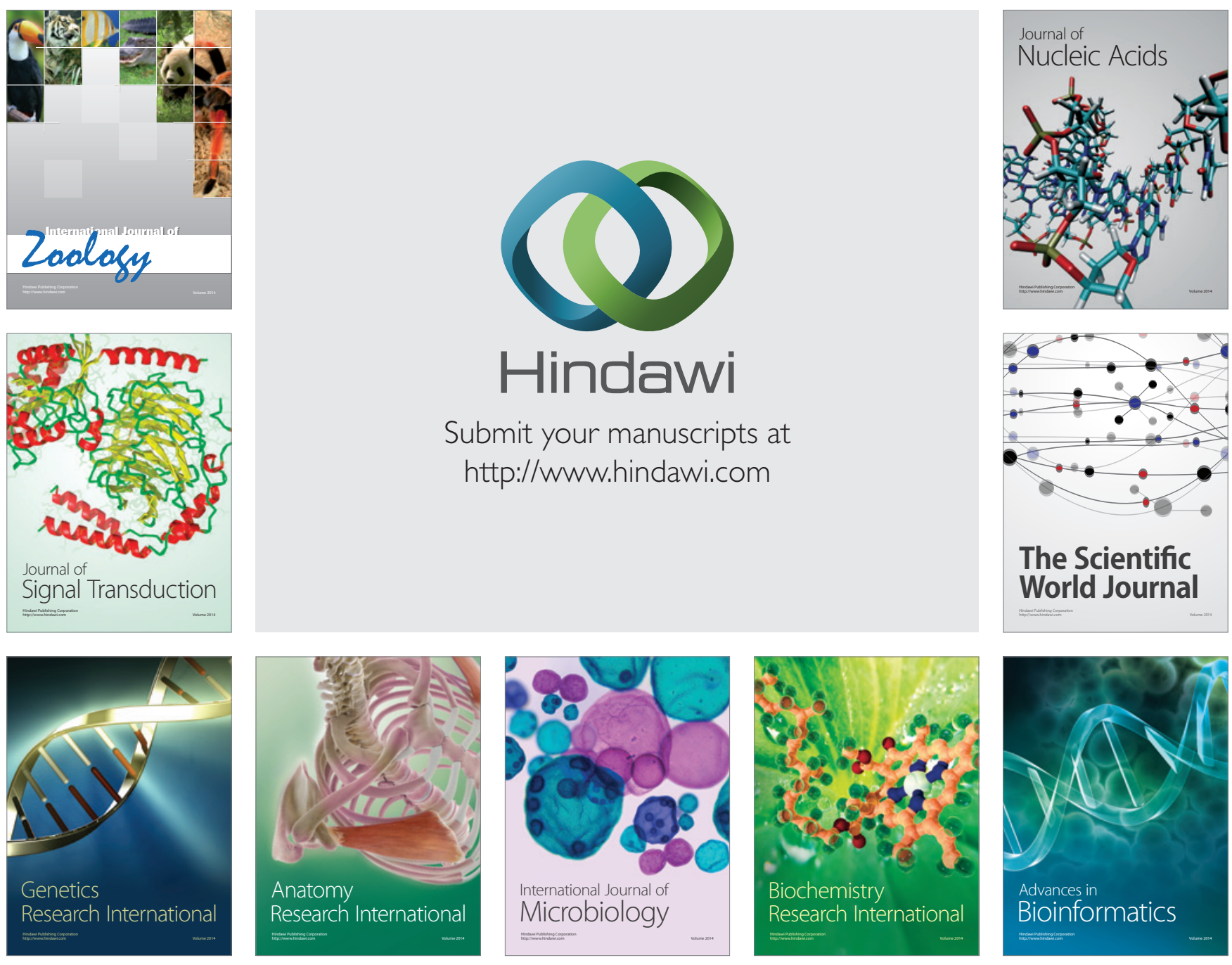

The Scientific World Journal
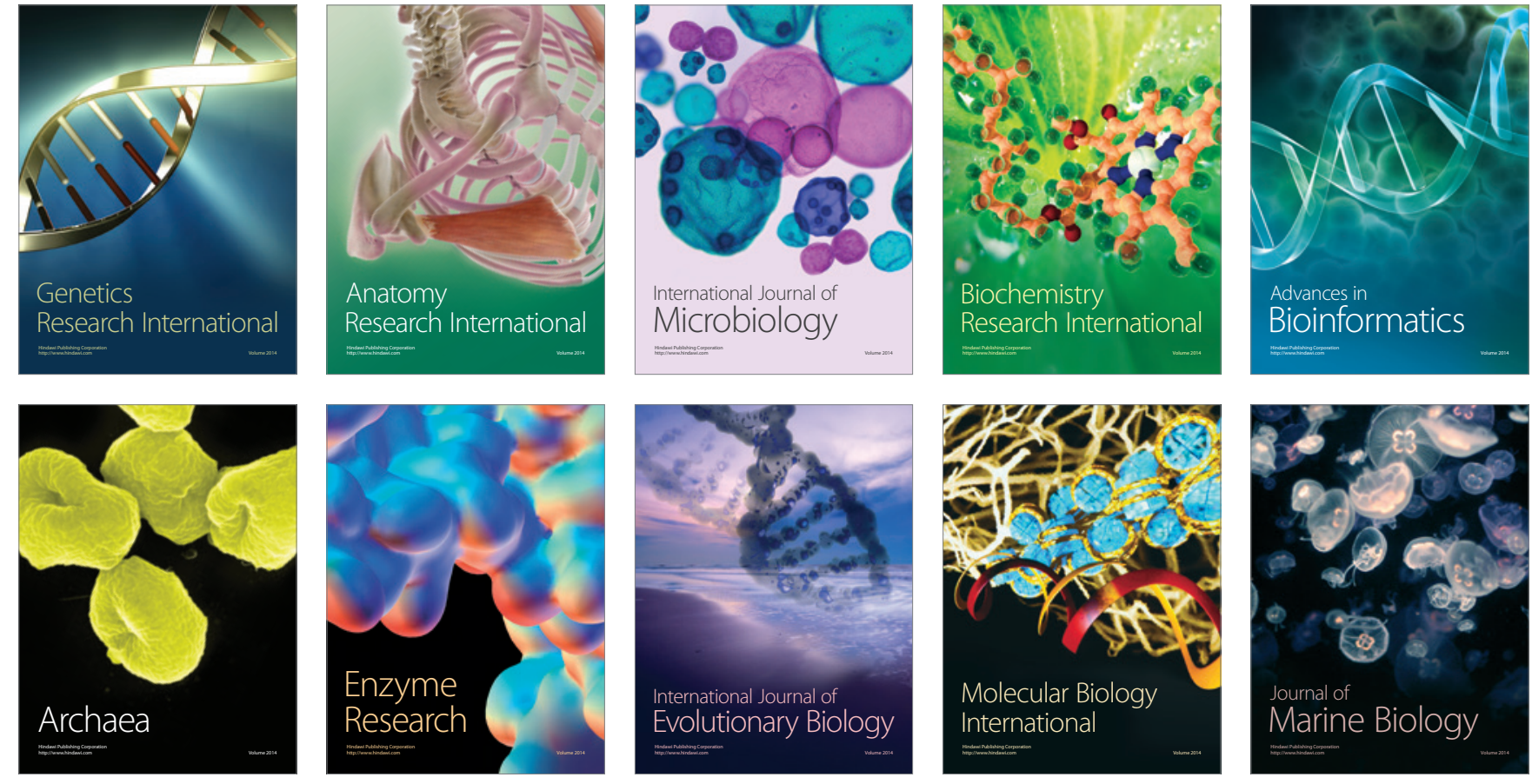